\title{
Cytological and Histopathological Correlation of Breast Lump: A 3 Year Study at Tertiary Care Center
}

\author{
Sanjaykumar C. Chauhan, Ankur N. Sarvaiya* \\ Dept. of pathology, GMERS Medical College, Himmatnagar, Gujarat, India
}

\begin{abstract}
Background: The fine needle aspiration cytology (FNAC) is an OPD procedure that is easy to perform, accurate, reproducible and cheap. Fine needle aspiration is a part of triple test to diagnose the breast lump. However a definitive conclusion should always be reached through histopathological examination

Aim: The aim of our study is to correlate cytological diagnosis with histopathological diagnosis, to know clonicomorphologic spectrum of breast lump, and to figure out sensitivity, specificity, positive predictive value, negative predictive value and efficiency of FNAC.

Methods: Total 244 cases who were subjected to FNAC and then subsequent biopsy was sent in each case were taken into consideration for analysis from tertiary care center in north Gujarat from February 2014 to January 2017 for 3 years.

Results: In our study, 4 were males and 240 were females( $1.64 \%$ and $98.36 \%$ respectively). Maximum cases of breast lump were in the 21 30 years age group. Out of total 244 cases $154(63.11 \%)$ were benign, 50(20.49\%) cases were malignant, 08 (3.27\%) were suspicious for malignancy and 32(13.11\%) were other nonneoplastic. Out of total 244 cases, 241 were consistent on histopathology and 3 were inconsistent. Our study have Sensitivity, Specificity, Positive predictive value, Negative predictive value, and Efficiency to be $98.24 \%, 98.93 \%, 96.55 \%$, $99.46 \%$ and $98.77 \%$ respectively.
\end{abstract}

Conclusion: FNAC helps the surgeon on further accurate management of lump as it is sensitive and specific. FNAC results should be correlated with clinical findings and radiological investigations. Inconclusive results and on FNAC should always be confirmed with biopsy.

\section{Keywords: Cytology, Biopsy, Histopathology, Breast lump}

\section{Introduction}

Breast lump is a common feature of most of the breast pathology. Many women in their life suffer from breast lump. Most of the breast lump cases are benign in nature. ${ }^{[1]}$ This lump feature can cause an anxiety in the patients. Breast cancer is second commonest type of cancer after cervical cancer in India. ${ }^{[2]}$ Mostly it also is presented as lump.

The fine needle aspiration cytology (FNAC) is an OPD procedure that is easy to perform, accurate, reproducible and cheap. ${ }^{[3,4]}$ Fine needle aspiration is a part of triple test. [5] Triple test consists of combined clinical examination, mammography and fine needle aspiration. However a definitive conclusion should always be reached through histopathological examination as it is universally accepted. Previously excisional biopsy was widely practiced, but preoperative evaluation by FNAC have number of benefits. ${ }^{[6,7]}$ FNAC can be done with ultrasonographic guidance for better results. ${ }^{[8]}$ It can also be used as an evaluation tool post lumpectomy. ${ }^{[9]}$ It can also evaluate male breast, accessory breasts and axillary lymph nodes accurately. ${ }^{[10,11]}$ In benign breast lesions triple test has reduced open biopsy rate. ${ }^{[12]}$
The aim of our study is to correlate cytological diagnosis with histopathological diagnosis, to know clonicomorphologic spectrum of breast lump, and to figure out sensitivity, specificity, positive predictive value, negative predictive value and efficiency of FNAC.

\section{Materials and Methods}

Total 244 cases who were subjected to FNAC and then subsequent biopsy was sent in each case were taken into consideration for analysis from tertiary care center in north Gujarat from February 2014 to January 2017 for 3 years. The study was retrospective in nature. Consent was taken for performing FNAC in every case. Findings about age, site, size, consistency, mobility, ulceration, pain, discharge, duration of lump, fixation to skin etc. were noted. Ultrasonography findings were noted wherever preformed. FNAC performed with $10 \mathrm{ml}$ syringe and $23 \mathrm{G}$ needle after proper cleaning of site with spirit and antiseptic solution. Findings on aspiration were noted. Material taken on glass slide spread with pressure by another glass slide. Slides fixed with methanol and then stained with hematoxylin and eosin stain for cytology. Slides mounted with cover 
slip by DPX. Biopsies sent from surgical department were grossed, processed and wax blocks prepared. Sections were taken from it and stained with hematoxylin and eosin.

FNAC findings have been concluded with different categories of diagnosis according to national cancer institute $(\mathrm{NCI})$ guidelines ${ }^{[13]}$ : benign, atypical, suspicious for malignancy, malignant and other nonneoplastic pathology. Subsequent histopathology findings were retrieved.

\section{Results}

Total 244 cases in which FNAC performed and subsequent biopsy received were taken for analysis. Table 1 shows age and sex wise distribution of these breast lump cases.

In our study out of 244, 4 were males (1.64\%) and 240 were females $(98.36 \%)$. Maximum cases of breast lump were in the 21-30 years age group.

Out of total 244 cases 154(63.11\%) were benign, $50(20.49 \%)$ cases were malignant, 08 (3.27\%) were suspicious for malignancy and 32(13.11\%) were other nonneoplastic.

In our study 154 cases were diagnosed as benign on cytology. Out of which 142 were fibroadenomas, 7 were fibrocystic disease, 2 were tubular adenoma, 2 were lactating adenoma and 1 was chronic non specific inflammation on histopathology. On FNAC reports, 50 cases were malignant.
On histopathology out of 50, 44 were infiltrating ductal carcinoma, 02 were infiltrating lobular carcinoma, 02 were medullary carcinoma and 2 were ductal carcinoma in situ. Eight cases were suspicious for malignancy, out of which 4 were infiltrating ductal carcinoma, 1 was ductal carcinoma in situ, 1 was mucinous carcinoma and 2 were sclerosing adenosis on histopathology. On other non neoplastic cases, 1 galctocele case was malignant on biopsy.

In confirmed benign and malignant reports on cytology subsequent histopathology reports were consistent in all cases. Out of 8 suspicious for malignancy reports on cytology two turned out to be sclerosing adenosis (benign). Out of total 244 cases, 241 were consistent on histopathology and 3 were inconsistent.

The chi square statistic is 3.0844. The p-value is 0.79047 . It is significant at $p<0.10$ but it is not significant at $\mathrm{p}<0.05$. So, FNAC is not the gold standard for diagnosing breast lump and it should be followed by biopsy in inconclusive results.

Positive cases on statistics are malignant cases or suspicious for malignancy cases (58) and negative cases were benign cases and other cases (186). So our study have Sensitivity, Specificity, Positive predictive value, Negative predictive value, and Efficiency to be $98.24 \%, 98.93 \%, 96.55 \%$, $99.46 \%$ and $98.77 \%$ respectively.

Table 1: Age and sex distribution of breast lump cases.

\begin{tabular}{|c|c|c|c|c|}
\hline Age (years) & Males & Males (\%) & Females & Females(\%) \\
\hline $11-20$ & 0 & 0 & 40 & 16.66 \\
\hline $21-30$ & 1 & 25 & 84 & 20 \\
\hline $31-40$ & 1 & 25 & 48 & 11.66 \\
\hline $41-50$ & 0 & 0 & 18 & 7.5 \\
\hline $51-60$ & 1 & 25 & 16 & 6.66 \\
\hline $61-70$ & 0 & 0 & 04 & 1.66 \\
\hline $71-80$ & 1 & 25 & 02 & 0.83 \\
\hline $81-90$ & 0 & 0 & 240 & 100 \\
\hline Total & 4 & 100 & & \\
\hline
\end{tabular}

Table 2: Cytological diagnosis

\begin{tabular}{|l|c|c|}
\hline Cytological diagnosis & Number of cases & Percentage \\
\hline Benign & 154 & 63.11 \\
\hline Malignant & 50 & 20.49 \\
\hline Suspicious for malignancy & 08 & 3.27 \\
\hline Other (non neoplastic) & & \\
\hline Inflammatory & 06 & 2.45 \\
\hline Fibrocystic & 08 & 3.27 \\
\hline Galactocele & 06 & 2.45 \\
\hline Gynecomastia & 04 & 1.63 \\
\hline Nonspecific & 08 & 3.27 \\
\hline Total & $\mathbf{2 4 4}$ & $\mathbf{1 0 0}$ \\
\hline
\end{tabular}


Table 3: Cytological and histopathological correlation.

\begin{tabular}{|c|c|c|c|c|c|c|c|c|c|c|c|c|c|c|c|}
\hline$\frac{\text { 응 }}{\sum_{0}^{\circ}}$ & 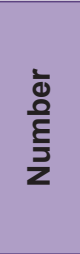 & 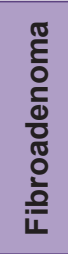 & 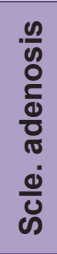 & 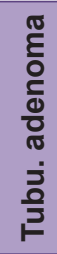 & 员 & $\stackrel{\cup}{\underline{J}}$ & $\frac{\boldsymbol{n}}{\mathrm{U}}$ & 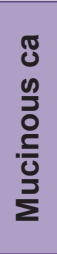 & $\begin{array}{l}\mathbb{J} \\
\frac{Z}{\sigma} \\
\overline{\bar{J}} \\
\frac{2}{0} \\
\frac{d}{\Sigma}\end{array}$ & 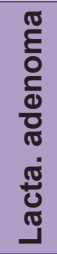 & 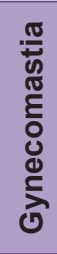 & 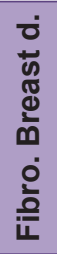 & 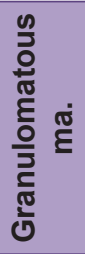 & 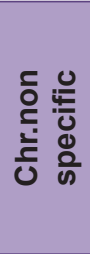 & $\begin{array}{l}\bar{\pi} \\
\stackrel{0}{0}\end{array}$ \\
\hline Benign & 154 & 142 & 00 & 02 & 00 & 00 & 00 & 00 & 00 & 02 & 00 & 07 & 00 & 01 & 154 \\
\hline Malignant & 50 & 00 & 00 & 00 & 44 & 02 & 02 & 00 & 02 & 00 & 00 & 00 & 00 & 00 & 50 \\
\hline Suspicious & 08 & 00 & 02 & 00 & 04 & 00 & 01 & 01 & 00 & 00 & 00 & 00 & 00 & 00 & 08 \\
\hline Inflammatory & 06 & 04 & 00 & 00 & 00 & 00 & 00 & 00 & 00 & 00 & 00 & 02 & 00 & 00 & 06 \\
\hline Fibrocystic & 08 & 00 & 00 & 00 & 00 & 00 & 00 & 00 & 00 & 00 & 00 & 08 & 00 & 00 & 08 \\
\hline Galactocele & 06 & 00 & 00 & 00 & 01 & 00 & 00 & 00 & 00 & 00 & 00 & 00 & 01 & 04 & 06 \\
\hline Gynecomastia & 04 & 00 & 00 & 00 & 00 & 00 & 00 & 00 & 00 & 00 & 04 & 00 & 00 & 00 & 04 \\
\hline Non specific & 08 & 00 & 00 & 00 & 00 & 00 & 00 & 00 & 00 & 00 & 00 & 00 & 01 & 07 & 08 \\
\hline Total & 244 & 146 & 02 & 02 & 49 & 02 & 03 & 01 & 02 & 02 & 04 & 17 & 02 & 12 & 244 \\
\hline
\end{tabular}

*Scle. $=$ sclerosing, tubu.=tubular, IDC=infiltrating ductal carcinoma, ILC=infiltrating lobular carcinoma, DCIS=ductal carcinoma in situ, $\mathrm{ca}=$ carcinoma, Lacta. $=$ lactating, Fibro. $=$ fibrocystic, ma. $=$ mastitis, chr. $=$ chronic

Table 4: Cyto histopathological comarison.

\begin{tabular}{|l|c|c|c|c|}
\hline \multirow{2}{*}{ Cytology diagnosis } & \multirow{2}{*}{ Number of cases } & \multicolumn{3}{|c|}{ Histopathology diagnosis } \\
\cline { 3 - 5 } & & Consistent & Inconsistent & Total \\
\hline Benign & 154 & $154(100 \%)$ & $00(00 \%)$ & 154 \\
\hline Malignant & 50 & $50(100 \%)$ & $00(00 \%)$ & 50 \\
\hline Suspicious of malignancy & 08 & $06(75 \%)$ & $02(25 \%)$ & 08 \\
\hline Other & 32 & $31(96.87 \%)$ & $01(3.13 \%)$ & 32 \\
\hline Total & $\mathbf{2 4 4}$ & $\mathbf{2 4 1 ( 9 8 . 7 7 \% )}$ & $\mathbf{0 3 ( 1 . 2 3 \% )}$ & $\mathbf{2 4 4}$ \\
\hline
\end{tabular}

Table 5: benign and malignant cases on cytology and histopathology.

\begin{tabular}{|l|c|c|c|}
\hline & Benign (histopathology) & Malignant(histopathology) & Total \\
\hline Benign(cytology) & 185 & 1 & 186 \\
\hline Malignant (cytology) & 56 & 2 & 58 \\
\hline Total & $\mathbf{2 4 1}$ & $\mathbf{3}$ & $\mathbf{2 4 4}$ \\
\hline
\end{tabular}

Table 6: Cytological diagnosis compared with previous published studies.

\begin{tabular}{|l|c|c|c|c|c|c|}
\hline Author & Inadequate & Benign & $\begin{array}{c}\text { Suspicious } \\
\text { for malignant }\end{array}$ & Malignant & Other & Total \\
\hline Debra et al[14] & $230(13.69 \%)$ & $1019(60.65 \%)$ & $300(17.85 \%)$ & $131(7.79 \%)$ & 0 & $\mathbf{1 6 8 0}$ \\
\hline Feichter G et al[16] & $239(16.23 \%)$ & $1003(68.13 \%)$ & $49(3.32 \%)$ & $181(12.29 \%)$ & 0 & $\mathbf{1 4 7 2}$ \\
\hline Desouza rocha P et al[17] & $9(1.07 \%)$ & $640(76.46 \%)$ & $26(3.10 \%)$ & $99(11.83 \%)$ & $63(7.52 \%)$ & $\mathbf{8 3 7}$ \\
\hline Singh K et al[18] & 0 & $200(83.33 \%)$ & $5(2.08 \%)$ & $35(14.58 \%)$ & 0 & $\mathbf{2 4 0}$ \\
\hline Mohammad Q et al[15] & $16(13.79 \%)$ & $68(58.62 \%)$ & 0 & $32(27.58 \%)$ & 0 & $\mathbf{1 1 6}$ \\
\hline Bukhari et al[19] & 0 & $271(63.76 \%)$ & $32(7.52 \%)$ & $120(28.23 \%)$ & $2(0.47 \%)$ & $\mathbf{4 2 5}$ \\
\hline Shrestha et al[20] & $27(1.92 \%)$ & $618(44.04 \%)$ & $175(12.47 \%)$ & $152(10.83 \%)$ & $431(30.01 \%)$ & $\mathbf{1 4 0 3}$ \\
\hline Rupom TU et al[21] & $3(0.57 \%)$ & $431(82.25 \%)$ & $17(3.24 \%)$ & $72(13.74 \%)$ & $4(0.76 \%)$ & $\mathbf{5 2 4}$ \\
\hline Our study & 0 & $154(63.11 \%)$ & $8(3.27 \%)$ & $50(20.49 \%)$ & $32(13.11 \%)$ & $\mathbf{2 4 4}$ \\
\hline
\end{tabular}


Table 7: Comparison of accuracy on FNAC

\begin{tabular}{|c|c|c|c|c|c|}
\hline Author & Sensitivity & Specificity & $\begin{array}{c}\text { Positive } \\
\text { predictive value }\end{array}$ & $\begin{array}{c}\text { Negative } \\
\text { predictive value }\end{array}$ & Efficiency \\
\hline Kline TS et al ${ }^{[22]}$ & 89.5 & 92.5 & 85.33 & - & 91.63 \\
\hline Dominguez F et al ${ }^{[23]}$ & 93.49 & 95.73 & 93.49 & 95.73 & 98.75 \\
\hline Feichter et al[16] & 86 & 99.3 & 99.3 & 85 & 93 \\
\hline Desouza rocha $P$ et al ${ }^{[17]}$ & 93.8 & 98.21 & 92.7 & - & 97.40 \\
\hline Singh $A$ et al ${ }^{[24]}$ & 84.6 & 100 & - & - & 92.3 \\
\hline Khemka A et al[25] & 96 & 100 & 100 & 95.12 & - \\
\hline Bukhari et al[19] & 98 & 100 & 97 & 100 & 98 \\
\hline Muhamed et al[26] & 90.6 & 100 & 100 & 99 & - \\
\hline Rubin et al ${ }^{[27]}$ & 87 & 100 & 100 & 89 & - \\
\hline Ishikawa et al[28] & 86.3 & 98.2 & 97.9 & - & - \\
\hline Collaco et al[29] & 92.1 & 98.1 & 99.4 & 98.1 & - \\
\hline Jan et al[06] & 92.6 & 98.48 & - & - & - \\
\hline Our study & 98.24 & 98.93 & 96.55 & 99.46 & 98.77 \\
\hline
\end{tabular}

\section{Discussion}

Fine needle aspiration cytology is globally recognized method as initial investigation and screening of breast lump. In our study fibroadenoma was commonest benign lesion and infiltrating duct carcinoma was commonest malignant lesion. These results are comparable with Debra et $\mathrm{al}^{[14]}$ and Mohammad $\mathrm{Q}$ et $\mathrm{al}^{[15]}$.

Our study have $63.11 \%$ benign, $3.27 \%$ suspicious for malignancy, $20.49 \%$ malignant and $13.11 \%$ other nonneoplastic cases on FNA cytology reports. These results have been compared with other previous studies in above table.

Table 7 shows comparison of statistical values of our study with various other previously published studies.

A single case of galactocele was given on FNAC on the basis of aspiration and cytology findings. Patient was 40 years old and was having 6 month old child. $0.5 \mathrm{ml}$ whitish fluid was aspirated on FNAC with $23 \mathrm{G}$ needle and $10 \mathrm{ml}$ syringe. On ultrasonography finding, it was irregular hypoechoic mass lesion. So, biopsy was advised. Infiltrating ductal carcinoma was given on subsequent biopsy.

Two cases were suspicious for malignancy on FNACs. One case was 38 years and other 46 years old. On palpation, it was hard, fixed and nonmobile swelling. On cytology, cellular pleomorphism and high nuclear to cytoplasmic ratio was present in few cells. So it was concluded as suspicious on FNAC. Biopsy was advised. On biopsy, it was sclerosis adenosis in both cases.

\section{Conclusion}

The fine needle aspiration cytology of breast lump is easy, valuable, cost effective, time saving and worldwide recognized method for initial investigation and screening of breast lump. It helps the surgeon on further management of lump as it is sensitive and specific. FNAC results should be correlated with clinical findings and radiological investigations. Inconclusive results on FNAC should always be confirmed with subsequent biopsy as histopathology is currently gold standard for diagnosis.

\section{References}

1. Cochrane RA, Singhal H, Monypenny IJ, Webster DJ, Lyons $\mathrm{K}$, Mansel RE: Evaluation of general practitioner referral to a specialist breast clinic according to the $\mathrm{U} \mathrm{K}$ national guidelines. Eur J Surg Oncol; 1997; 23: 198-201.

2. Sandhu DS, Sandhu S, Karwasra RK, Marwah S: Profile of breast cancer patients at a tertiary care hospital in north India. Indian J Cancer; 2010; 47: 16-22.

3. Rimm DL, Stastny JF, Rimm EB, Ayer S, Frable WJ: Comparison of the costs of fine needle aspiration and open surgical biopsy as methods for obtaining a pathologic diagnosis. Cancer; 1997; 81: 51-56.

4. Silverman JF, Lannin DR, O’Brien K, Norris HT: The triage role of fine needle aspiration biopsy of palpable breast masses. Diagnostic accuracy and cost effectiveness. Acta Cytol; 1987; 31: 731-736.

5. Kaufmanz, Shpitz B, Shapiro M, Rona R, Lew S, Dinbar A. Triple approach in the diagnosis of dominant breast masses: combined physical examination, mammography and Fineneedle aspiration, J. SurgOncol 1994; 56: 254-7. 
6. Jan WA, NaikZada, Samieullah, Israr M. Comparison of FNAC and core biopsy for evaluating breast lumps. J coll physicians Surg. Pak. 2002; 12: 686-688.

7. Patrikar A, Maimoon S and Mahore S. Filarial granuloma in breast. Ind Jour Pat Mic 2008;23, 116 -122.

8. Phillips G, McGuire L, Clowes D: The value of ultra sound guidance fine needle aspiration in the assessment of solid breast lumps. Australas Radiol; 1994; 38: 187-92.

9. Ku NN, Mela NJ, Fiorica JV, et al: Role of fine needle aspiration cytology after lumpectomy. Acta Cytol; 1994; 38 : 927-32.

10. Bhagat P, Kline TS: The male breast and malignant neoplasms; diagnosis by aspiration biopsy cytology. Cancer; 1990; 65: 2338-41.

11. Dey P, Karmakar T: Fine needle aspiration cytology of accessory axillary breast and their lesions. Acta Cytol; 1994; 38: 915-6

12. Green B, Dowley A, Turnbull LS, Smith PA, Leinster SJ, Winstanley JH: Impact of fine needle aspiration cytology, ultrasonography and mammography on open biopsy rate in patients with beningn breast disease. Br J Surg; 1995; 82: 1509-1511.

13. National cancer institute fine-needle aspiration of breast workshop subcommittees. The uniform approach to breast fine-needle aspiration biopsy. Diagn Cytopathol. 1997;16(4):295-311.

14. Debra AB, Hajdu SI, Urban JA, Gaston JP. Role of aspiration cytology in diagnosis and management of mammary lesions in office practice.Cancer.1983; 7:1182-1189.

15. Mohammad Q, Akbar SA, Ali J and Mustafa S: Lump in breast; Role of FNAC in diagnosis. Professional Med J. 2009;16(2):235-238.

16. Feichter GE, Haberthur F, Gobat S, Dalquen P .Statistical analysis and cytohistologic correlations. Acta Cytologica. 1973;17:188-190.

17. DeSouza Rocha P, Nadkarni NS and Menez S. Fine needle aspiration biopsy of breast lesion and histopathologic correlation. Acta Cytologica.1997; 41.

18. Singh K, Sharma S, Dubey VK, Sharma PR. Role of FNAC in diagnosis of breast lumps. JK Science. 2001;3(3):126-128.
19. Bukhari M.H, Arshad M, Jamal S, Niazi S, Bashir S, Bakshi I et al: Use of Fine-Needle Aspiration in the Evaluation of Breast Lumps. Pathology research International.2011; Article ID 689521, 10 pages. doi:10.4061/2011/689521.

20. Shrestha A, Chalise S, Karki S and Shakya G. Fine needle aspiration cytology in a palpable breast lesion. Journal of Pathology of Nepal. 2011; 1:131-135.

21. Rupom TU, Choudhary T. Study of Fine Needle Aspiration cytology of breast Lump of Breast Lump: Correlation of Cytologically Malignant Cases with Their Histological Findings. BSMMU J.2011; 4(2):60-64.

22. Kline TS, Joshi LP, Hunter SN. Fine needle aspiration of the breast: diagnoses and pitfalls.Cancer.1979; 44:1458-1464.

23. Dominguez F, Riera JR, Tojo S and Junco P. Fine needle aspiration of breast masses, an analysis of 1398 patients in a community hospital. Acta cytological.1997; 41(2):341-347.

24. Singh A, Haritwal A and Murali BM. Pattern Of breast Lumps and Diagnostic Accuracy Of Fine Needle Aspiration Cytology; A Hospital Based Study from Pondicherry, India. The Internet Journal of Pathology.2011; 11(2):1-14.

25. A Khemka, N Chakrabarti, S Shah, V Patel. Palpable Breast Lumps: Fine-Needle Aspiration Cytology versus Histopathology: a Correlation of Diagnostic Accuracy. The Internet Journal of Surgery. 2008 Volume 18 Number 1.

26. Muhamed AZ, Edino ST, Ochicha O, Alhasan Su. TheValue of Fine-needle aspiration biopsy in preoperative diagnosis of palpable breast lumps in resource-poor countries: a Nigerian experience. Annals of African Medicine 2005; 4: $19-22$

27. Rubin J, Horiuchi K, Joy N, Haun W, Read R, Ratzer E, Fenoglio M. Use of FNAC for solid breast lesions is accurate and cost effective. Am J Surg 1997; 174: 694-6.

28. Ishikawa $\mathrm{T}$, Hamaguchi $\mathrm{Y}$, Tanabe $\mathrm{M}$, Momiyama $\mathrm{N}$, Chishima J, Nakatini Y, Nozawa A, Sasaki T, Kltamura H, Shimada H. False positive and false negative cases of fine needle aspiration cytology for breast lesions. BreastCarcinoma 2007; 14: 388-92.

29. Collaco LM, De Lma R-c Werner B. Torres LP. Value of fine needle aspiration in diagnosis ct Breast lesion. Actacytoi 1999; 43: 587-92.

*Corresponding author:

Dr. Ankur N Sarvaiya, Assistant professor, dept. of pathology, GMERS Medical College, Himmatnagar. Gujarat, India

Phone: +91 9974149292

Email: ankur.sarvaiya@gmail.com

Financial or other Competing Interests: None.

Date of Submission : 01.03.2017

Date of Acceptance : 01.04.2017

Date of Publication : 04.07.2017 